CORRECTION

\title{
Correction: Light correlated color temperature and task switching performance in preschool-age children: Preliminary insights
}

\section{The PLOS ONE Staff}

The following information is missing from the Funding section: Publication of this article was funded by the University of Colorado Boulder Libraries Open Access Fund.

The publisher apologizes for the error.

\section{Reference}

1. Hartstein LE, LeBourgeois MK, Berthier NE (2018) Light correlated color temperature and task switching performance in preschool-age children: Preliminary insights. PLoS ONE 13(8): e0202973. https:// doi.org/10.1371/journal.pone.0202973 PMID: 30161180

\section{Gopenaccess}

Citation: The PLOS ONEStaff (2018) Correction: Light correlated color temperature and task switching performance in preschool-age children: Preliminary insights. PLOS ONE 13(10): e0205542. https://doi.org/10.1371/journal.pone.0205542

Published: October 4, 2018

Copyright: @ 2018 The PLOS ONE Staff. This is an open access article distributed under the terms of the Creative Commons Attribution License, which permits unrestricted use, distribution, and reproduction in any medium, provided the original author and source are credited. 